\title{
A SOCIOLOGICAL TURN IN STATEBUILDING RESEARCH?
}

\author{
By Benjamin Brast (2013)
}

This paper is an accepted manuscript (AM). The article has been published in:

Journal of Intervention and Statebuilding, 7 (4), p. 530-540.

http://dx.doi.org/10.1080/17502977.2013.804319

Exit Strategies and State Building edited by Richard Caplan. Oxford: Oxford University Press, 2012. Pp. 320 + xii + index. £22.50 (pbk.). ISBN 978-0-19-976012-1.

New Agendas in Statebuilding: Hybridity, contingency and history edited by Robert Egnell and Peter Haldén. London: Routledge, 2013. Pp. 246 + xii + bibliography + index. $£ 80.00$ (hbk). ISBN 978-0-415-66071-6.

Statebuilding and State-Formation: The political sociology of intervention edited by Berit Bliesemann de Guevara. London: Routledge, 2012. Pp. $259+x v+$ index. £85.00 (hbk). ISBN 978-0-415-67697-7.

Are we experiencing a sociological turn in the study of statebuilding? In order to answer this question, it is necessary to delineate the discipline of sociology. Max Weber (1978: 4) defined sociology as "[..] a science concerning itself with the interpretive understanding of social action and thereby with a causal explanation of its course and consequences". Like all definitions, the Weberian is a contested one. Nevertheless, it might provide a useful starting point. In comparison to mainstream political science, there are some important differences. The main dividing line is certainly that sociology is not restricted to the political sphere, but is concerned with society as a whole. It deals not just with causal explanation of social behavior, but also with understanding human action. In addition, sociologists have extensively discussed and conceptualized the relation between individuals and social structure (e.g. Elias 1978; Giddens 1984). Taken together, these features have made sociological approaches highly valuable for International Relations Constructivists. Hence, the discipline of IR has experienced a revival of sociological approaches since the end of the 1990s, and the theories of thinkers such as Foucault, Giddens or Habermas have increasingly been adopted by IR scholars ${ }^{1}$.

In contrast to the wider discipline, the sub-field of statebuilding research has largely ignored this trend until very recently. From a substantial point of view, it is rather surprising that sociology has received so little attention by scholars who examine the difficulties of building states in post-colonial, post-conflict settings. Historically, sociology emerged mainly as an effort to understand what happened to European societies in the process of modernization (Lawson and Shilliam 2010: 71). State formation, and the relation between the state and society in particular, has received much attention by sociologists such as Émile Durkheim (1893[1964]), Max Weber (1978), Norbert Elias (1939[2000]), or Charles Tilly (1992). These types of macro sociology offer a rich set of theoretical and methodological tools that can be fruitfully applied to study the effects of statebuilding interventions. As this review

\footnotetext{
${ }^{1}$ For a detailed discussion of the link between sociology and IR: Lawson, George and Robbie Shilliam. 2010.

"Sociology and international relations: legacies and prospects." Cambridge Review of International Affairs 23(1):69-86.
} 
essay shows, scholars of statebuilding increasingly realize this potential and offer innovative analyses of statebuilding.

One possible explanation for this turn to sociology is that of timing. Since the era of liberal statebuilding has now entered its third decade, several interventions have ended (e.g. Iraq, Sierra Leone), while others are scheduled to end soon (e.g. Afghanistan). In some cases, there is no end in sight, although these operations have been ongoing for up to two decades (e.g. Bosnia, DRC). Therefore, it seems to be time to put contemporary statebuilding into a wider macro sociological perspective. One question in particular comes to the forefront of scholarly attention: What place do statebuilding interventions occupy in the long-term state formation processes of post-colonial states?

The books reviewed in this essay reflect to a certain degree the evolution which is currently taking place within the field of statebuilding studies. Richard Caplan's edited volume deals with the question of how external actors can end statebuilding projects. It is a classical piece of statebuilding scholarship that does not resort to sociological approaches. In contrast, the two other edited volumes under review apply a host of sociological theories and methods. As this review shows, this turn to sociology produces promising results.

\section{WALKING, NOT RUNNING FOR THE EXIT}

In Exit Strategies and State Building (2012), Richard Caplan (of Oxford University) and fifteen of his colleagues try to answer the question how an orderly exit from statebuilding interventions can be planned and executed by external actors. Their main argument is that the exit has received too little attention from both scholars and policymakers alike. This is unfortunate, since a hasty and unplanned exit can jeopardize what has been achieved in years of costly statebuilding. Hence, they argue that a thorough analysis of exit strategies is needed.

Richard Caplan deserves great credit for organizing the book in a very coherent manner, something that one does not often encounter when reading edited volumes in the discipline of political science. The book is organized into an introduction and five main sections. Four of these sections deal with different types of 'interventions': colonial administrations, peace support operations, international administrations, and military occupations. Each section starts with a conceptual chapter that defines and discusses a certain type of intervention. It is then followed by case studies that apply the overall framework to specific interventions. A final chapter deals with 'thematic issues', which include normative visions, the political economy of exit and a conclusion. This organization makes the book easy to read and more accessible to a broader audience.

In the brief introduction, Caplan provides the reader with the volume's main agenda. He argues that 'exit' should be conceptualized not as "[..] a single moment or event" (p. 5). Instead, "[if] one assumes a fairly high degree of international involvement, as is generally the case with internationally led state-building operations, then exit is best understood as a process of transition" ( $p$. 5). Thus, an exit marks the withdrawal of a certain actor and can imply a handover of responsibility to either local or other international actors (p. 5). 'Exit' should not be confused with 'mandate implementation', since a failure of achieving one's goals could still be followed by a successful exit. In these cases, external actors will have to define what post-intervention results could still be acceptable and what type of transition would secure such an outcome (p. 5-6). Caplan also presents a typology of exit mechanisms: cut and run, phased withdrawal, deadlines, benchmarking, elections, and successor operations. Empirically, there has been a tendency to shift the focal point of exit from conducting elections (as happened in Namibia or Cambodia) to more ambitious goals that are benchmarked (p. 911). As this chapter shows, neither of the major actors of statebuilding (US, UN) has an exit doctrine that could guide the conceptualization of exit strategies, although the UN is increasingly aware of the issue (p. 6-9). 
The first section on colonial administrations offers an interesting historical perspective. In the conceptual chapter, John Darwin (Oxford University) argues that there are two central factors which have an impact on the likelihood of successful exit: International context and ideological context. On the international level, strong consensus among major actors and clear goals are conducive to a good exit strategy. As the author argues, most colonial exits fell short of this ideal (p. 22-26). On the ideological level, chances of success increase when most affected actors see policy choices as legitimate. In this respect, the global rise of nationalism and a norm of self-governance provided a focal point for international and local actors (p. 26-29). Despite the racist and authoritarian character of colonial rule itself, colonial powers often tried to install liberal institutions during their exits. During this process they had to deal with obstacles such as ethnic conflicts, weak institutional capacity, and patrimonial networks, many of which were the direct result of colonialism. Additionally, these exits happened mostly on short notice and, thus, often lacked coherent strategies (p. 31-36). In sum, the section shows that colonial history might offer some lessons for today's statebuilders because exiting colonial powers faced some of the same problems.

A good example of how the exit strategy perspective can shed new light on well-known contemporary cases is Toby Dodge's (LSE) take on the exit strategies of the US and the UK in Iraq. While the chapter does not offer new empirical material, it skillfully analyzes the Iraq War from the exit angle. Dodge shows that the US was almost constantly searching for a viable exit plan once initial expectations were not met. The pre-invasion plan was to simply remove the Baathist leadership while leaving most of the state institutions intact, and pull out most troops within a few months (p. 245-246). Once this proved illusionary, the exit plan was changed to a radical de-Baathification and reconstruction effort that was meant to be executed within a 2-3 year time frame (p. 246-248). As Dodge convincingly argues, this plan collided with electoral politics in the US, so that it was quickly replaced by an 'Iraqization' strategy in the autumn of 2003. However, instead of leading a quick exit, this plan resulted in a devastating civil war (p. 248-250). Thus, in 2007 the US changed its strategy for a last time, combining a troops surge, new tactics, and a less ambitious political deal for withdrawal in 2011 (p. 252-254). This case study shows how exit strategies are often the result of a painful learning process, and successful exits often imply a failure to achieve the initial goals of an intervention.

One minor point of criticism is the at times excessive use of typologies. There seem to be so many different types of interventions and modes of exit that it becomes almost impossible to draw more general conclusions from comparison. Moreover, the different types of statebuilding categories are not always convincing. For instance, the section on 'military occupations' includes both the US occupation of Iraq and the Israeli occupation of Gaza. As Gregory Fox (Wayne State University) makes clear in the introductory chapter, this categorization is based solely on the legal argument that cases in which "[..] a state exercises actual control over another state's territory are considered occupations" (p. 199). Whether these two military operations are more similar to each other in terms of statebuilding than, for example, the Iraq war is to 'peace support operations' in Afghanistan or Sierra Leone, is highly debatable.

A more fundamental problem is the lack of critical reflection. This lack of distance from the political agenda can lead to failure in analyzing and understanding resistance against liberal statebuilding. William J. Durch's (Stimson Center, Washington D.C.) liking 'spoilers' in PSOs to 'ugly drunks' at a party (p. 87) is a case in point. The book might have benefited from a chapter that questions some basic assumptions and practices of statebuilding. By staying firmly in the liberal peacebuilding framework, the volume too often assumes a certain illegitimacy of 'non-liberal actors'. The critical scholarship on peacebuilding has already shown that this approach makes it difficult to understand local agency and legitimacy, both of which would we be necessary to create a sustainable state.

Moreover, after reading the book, one is left wondering whether liberal statebuilding is able to create a sovereign state at all. In his conclusion, Caplan argues that "[e]xit will not and should not 
necessarily mark the end of all international involvement in state-building" (p.312). He goes on to underline the importance of "[..] follow-on measures that can and should be taken in the wake of exit to reinforce post-conflict state-building achievements or, in the event of a failure to complete a mandate, to mitigate the effects of adverse developments" (p. 312-313). Hence, statebuilding rather appears as an open-ended operation with some external actors exiting and new external actors entering through a revolving door.

\section{NEW THEORIES FOR STATEBUILDING}

In New Agendas in Statebuilding: Hybridity, contingency and history (2013), Robert Egnell (Georgetown University) and Peter Haldén (University of Uppsala) make four major arguments: First, international statebuilders will always encounter certain pre-existing political structures that are the result of a long-term process of state-formation (p. 3). Second, the empirical reality of (post-colonial) states does not comply with ideal types of statehood, but will always be some form of hybrid order ( $p$. 3-4). Third, local context matters greatly and makes generalizations difficult (p. 4-5). And, fourth, a deeper theoretical understanding of the state is needed to examine statebuilding interventions (p. 5-6). The book is organized into three main sections: 'New theoretical approaches to statebuilding', 'Revisiting historical cases of statebuilding', and 'Strategic imperatives in statebuilding'. The structure of the book reflects the relative importance of theory, and not only because the theory section is the biggest one (four chapters). Theoretical innovation can be found across the whole volume. The implications for political decision-makers are trenchantly summarized by the authors in the conclusion: "[..]statebuilding, both in theory and practice, must be informed by a deep understanding of the state as a social and political entity, by the theory and history of state formation processes and by the specific local, regional and global contexts in which these endeavors are to take place" (p. 235).

One important insight from sociology is that society is not synonymous with 'population of a nation state'. Instead, society can be understood in regional or global terms. Peter Haldén shows how fruitful this insight can be for the study of state formation. In his chapter 'Against endogeneity', he makes the case that most research on statebuilding focuses on 'domestic' causes and processes of statebuilding (p. 35-37). By applying Norbert Elias' figurational sociology to IR, he shows that historically, the rise of nation states in Western Europe could only occur within an emergent state system (p. 40-45). Although this formulation sounds contradictory at first, he convincingly argues that the agent-structure-problem also applies to state formation: No single European state emerged on its own. States could only thrive in a regional system where political elites shared a belief in territoriality and sovereignty. The implication is that statebuilders have to take into account the regional political setting, as Haldén demonstrates by comparing the statebuilding success in Namibia with the failure in Afghanistan (p.45-50.

Closely connected and equally innovative, Gorst Harste's (Aarhus University) chapter proposes to study state formation with Niklas Luhmann's modern systems theory. Harste argues that sovereign, territorially organized statehood was the result of a complex communication process within a European society (97). Emerging states began to describe themselves in territorial terms, and this form of communication was copied by other political organizations across Europe. Hence, the idea of territoriality was increasingly accepted and self-referentially applied by 'state organizations' (p.97-103). "Territoriality is not the beginning of state formation; it is rather a result of state formation" (101-102). However, while offering insights into systems theory and state formation, this chapter would have greatly benefited from making a clear connection to statebuilding interventions.

The issue of exit is also tackled by one of the authors. Jan Angstrom (Uppsala University) argues "[..] that not including withdrawal as a key strategic tool is based on flawed institutionalized premises that action is better than inaction" (p.172). As an example, he applies this reasoning to the case of Afghanistan. He argues that it might have been necessary to militarily weaken the Taliban and support the government with building security forces. Having achieved these goals, however, NATO's presence has become in many ways the only major source of legitimacy for the insurgents. At the 
same time, it prevents the government from fully playing the nationalist card against Taliban forces supported by Pakistan (p. 174-182). Angstrom thus concludes that NATO achieved as much as one could expect given Afghanistan's social structure, and that state formation will now be enhanced by a complete withdrawal (p. 182-184). This chapter shows how taking state formation seriously can lead to counter-intuitive conclusions that could not be reached by applying the usual technocratic view.

Despite all its theoretical innovation, the volume clings to the political agenda of statebuilding. It is committed to statebuilding as a policy tool and sees sociological approaches as a way to make intervention more efficient (p. 236-237). While this normative commitment might preclude certain conclusions, the authors generally succeed in providing new perspectives. Their main argument could be summarized as: If societal structures inhibit the full realization of democracy, the rule of law or a free market economy, this should not be seen as failure but as a logical outcome of the clash between long-term structures and short-term statebuilding. Hence, policymakers and scholars need to accept the necessity of hybrid solutions.

\section{BOB THE (STATE-)BUILDER MEETS STATE-FORMATION}

Statebuilding and State-Formation (2012) is an edited volume that carries the sub-title 'The political sociology of intervention'. The editor, Berit Bliesemann de Guevara (University of Aberystwyth) assembled a group of international scholars to analyze how contemporary statebuilding interventions affect the longue durée of state formation processes. The book is divided into three major parts which deal with different aspects of interventions. 'State-formation, violence and political economy', 'Governance, legitimacy and practice in statebuilding and state-formation' and 'The international self statebuilders' institutional logics, social backgrounds and subjectivities'. The first two parts consist of chapters that deal with specific cases, whereas the third part also includes some more general considerations about 'statebuilders' (Veit/Schlichte, Smirl and Heathershaw). While the case studies are all interesting and insightful, the difference between section one and section two does not become very clear. However, the third part offers a lot of novel research on the very people that do statebuilding in the field.

Bliesemann de Guevara sets out the agenda in the introduction by arguing that statebuilding interventions clash with social structures and long-term state-formation processes. She argues that external actors often resemble Bob the Builder, a cartoon figure whose slogan is: 'Can we fix it? Yes we can!' (p. 1-2). This somewhat odd comparison is meant to underline that external actors as well as scholars approach statebuilding interventions with a 'can-do-mentality': If only the appropriate means and strategies are applied, statebuilding will succeed in exporting liberal statehood. However, she and her colleagues argue that the ability of external actors to export institutions is far more constrained by societal structures than mainstream political science commonly assumes (p. 11-13). Bliesemann de Guevara bases her analysis on the sociology of Norbert Elias, whose theory posits that societies need to solve the problems of material reproduction, violence control and symbolic order (p. 6-7). Applying this framework to statebuilding, she argues that state formation in the post-colonial world has taken very different trajectories than in Europe because it is highly 'internationalized': First, international inflows of money decouple state funding from society and, thereby, undermine state formation (p. 7-9). Second, the monopoly on the means of violence is either strongly contested or, where it exists, it is often not controlled by the general public (p. 9-10). And, third, states regularly fail to comply with the international norm of legal-rational institutions, and instead everyday life is governed by informal institutions whose legitimacy flows from different sources. Since the state is not detached from society but a part of it, it will work according to those rules and norms prevalent in society (p. 10-11). Hence, Bliesemann de Guevara argues that liberal statebuilding, with its top-down approach, often times exacerbates this internationalization of state formation without solving the underlying problems (p.1113). 
Lousie Riis Andersen's (Danish Institute for International Studies) chapter on statebuilding in Liberia is a good example of how local context clashes with external interventions. She conceptualizes the UNMIL as 'tacit trusteeship' by arguing that it was much more intrusive then officially alleged. One core instrument of international control was GEMAP, a program that was meant to curb corruption. Via GEMAP, external actors could veto spending decisions made by Liberian ministries. As Andersen shows, the program was initially opposed by the political elites of Liberia (p. 137). Over time, however, President Johnson Sirleaf realized that it was actually a tool to empower the presidency and sideline other decision-making bodies (p. 140-143). Her leverage was increased by the fact that the international authority was diffuse as different donor agents were working with different ministries ( $p$. 138-139). Andersen concludes that this "[...]confirms the assumption that purposeful attempts at statebuilding are always curbed in the complex social process of state-formation and underscores the importance of a dynamic analysis that avoids reifying political phenomena" (p. 143).

One of the most interesting chapters is provided by the editor herself. For their chapter, Bliesemann de Guevara and Goetze (University of Nottingham Ningbo, China) interviewed 69 'statebuilders' who had worked for UNMIK, the UN mission in Kosovo. They argue that international civil servants working in statebuilding environments are well aware of local complexities and contradictions of their work. However, they are not able to change their views and their strategies accordingly (p. 198-200). The authors resort to Bourdieu to explain this mismatch between knowledge and behavior. According to Bourdieu, individuals are socialized in certain social environments and, thereby, develop a specific 'habitus' that entails personal preferences, taste and world views. These views remain very stable over the course of a life. Statebuilding personnel are overwhelmingly liberal, cosmopolitan, and were raised in the upper middle class (p. 208-209). Therefore, while statebuilders experience the clash between local context and liberal statebuilding, they are not able to make wideranging concessions to local demands (p. 211).

In addition to this survey of statebuilders, Koddenbrock (University of Magdeburg) in his chapter analyzes how the individuals in the field imagine their host country. Smirl (University of Sussex) offers a compelling analysis of aid workers' memoirs. Both chapters broadly support an image of statebuilders as being rather concerned with their personal ideals and career choices than with the broader implications of statebuilding. Other innovative chapters on the 'international self' show how the external actors struggle with asymmetrical information between bush offices and headquarters (Veit/Schlichte, University of Bremen), or how there are conflicts over competencies and resources among different statebuilding agents (Hensell, University of Hamburg). By applying mostly micro sociological tools to the study of the external actors in liberal peacebuilding, the section on the 'international self' offers certainly one of the most innovative and intriguing analyses in an edited volume on statebuilding in the last few years.

One point that is not fully convincing about the book is Bliesemann's claim that there is a clear distinction between 'critical' and 'sociological' approaches. In many ways, critical scholars have advanced their arguments by applying a more sociological perspective early on. Hence, any sociological turn owes to the so-called critical scholarship of the last decade. However, by making explicit the assumptions underlying statebuilding, and by showing how interventions not only affect local but also international actors, 'State Formation and Statebuilding' offers a degree of reflection on the matter of statebuilding that is rare in the literature.

\section{A WELCOME TURN}

To sum up, the reviewed edited volumes display different degrees of 'sociologicalness'. Exit Strategies and State Building focuses on the 'exit phase' of statebuilding interventions, collects lessons learned from recent history and draws conclusions for ongoing and future statebuilding operations. As such, it is a good example of the type of policy-oriented work that has for long dominated the field. Richard Caplan and his fellow contributors fulfill this task very well. However, Egnell and Haldén criticize this 
type of literature as too technical and too strongly rooted in official policy discourses. Hence, their volume seeks to broaden the theoretical and philosophical access to matters of state-building and state formation. For this purpose, the authors resort to a variety of sociological theories that have so far received little attention from statebuilding researchers. This theoretical diversity is the biggest strength of the book and offers many new perspectives on statebuilding interventions. Although it utilizes sociological tools, New Agendas in Statebuilding is committed to improving Western statebuilding policies. While this is legitimate, it could still have the effect of creating a 'can do'-bias. Unlike the other two volumes, Bliesemann de Guevara's book is more agnostic about the necessity to intervene and build states. Such a more detached approach might enable the contributors to make clearer and less biased judgments when analyzing the (im-)possibility of external statebuilding. On the one hand, one might dispute the practical relevance of such a clear division between science and policy advice. On the other hand, books like State Formation and Statebuilding might provide less biased input for societal debate on fundamental questions concerning interventions and peacebuilding. Notwithstanding the above, both New Agendas in Statebuilding and State Formation and Statebuilding exemplify how much analytical leverage can be gained by paying attention to sociological theories and methods.

As these books show, a political sociology approach to statebuilding has several benefits, three of which were most pronounced when reviewing the edited volumes: First, researchers can broaden their focus by examining not only political actors and institutions, but also a wider set of societal actors and structures. This allows scholars to overcome a strict and artificial separation of state and society. At the same time, society does not stop at national borders, so that the wider regional setting needs to be taken into account. Second, political scientists can learn from sociologists to make a greater effort to understand the motivations of all actors involved. This means taking local populations more seriously as well as analyzing the external actors in more detail. Third, the sociological literature shows that the question of agency and structure is crucial for all social analyses. In the context of statebuilding, it is not enough to create national institutions that set the right incentives. These new sets of rules collide with existing informal institutions. Adding to the problem is the fact that individuals are socialized in a given context and will not easily change their preferences and values. Thus, social structures possibly constrain statebuilding to a much greater extent than is commonly acknowledged in the 'problem-solving literature'. Related to this is the utility of paying attention to macro sociological research on European state formation. Key insights from this literature include the importance of economic structures, the socialization of populations into state rule, and the fact that state formation was historically a very violent process.

However, the new sociological literature still lacks coherence. Authors make use of a patchwork of theories, many of which are often incompatible with each other. While this might be partly excused by the explorative character of the two sociological books reviewed here, there is nonetheless a lot of room for improvement. The next step on the way to a political sociology of statebuilding should be to work on frameworks based on specific sociological theories. Coherent, book-length analyses of statebuilding from the perspectives of Elias, Foucault, Luhmann or Giddens would further increase the analytical leverage that can be gained from sociology.

A final remark might concerns the independence of statebuilding research. Both Exit strategies and New Agendas have been supported by governmental agencies. Among the supporters of Caplan's book ranks NATO, while New Agendas was supported by the Swedish army. Such proximity to those actors who conduct statebuilding is not without risks for scholarly independence, and it might be time to discuss whether and how such collaborations should be conducted by social scientists. 


\section{Notes on the contributor:}

Benjamin Brast is PhD Fellow at the Bremen International Graduate School of Social Sciences (University of Bremen / Jacobs University). He writes on statebuilding interventions and International Relations, and can be contacted at bbrast@bigsss-bremen.de

\section{REFERENCES}

Bliesemann de Guevara, Berit. 2012. Statebuilding and state-formation : the political sociology of intervention. London and New York: Routledge.

Caplan, Richard. 2012. Exit strategies and state building. Oxford and New York: Oxford University Press. Durkheim, Émile. 1893[1964]. The division of labor in society. New York: Free Press of Glencoe.

Egnell, Robert and Peter Haldén eds. 2013. New agendas in statebuilding : hybridity, contingency and history. London and New York: Routledge.

Elias, Norbert. 1939[2000]. The civilizing process : sociogenetic and psychogenetic investigations. Rev. Edition. Oxford ; Malden, Mass.: Blackwell Publishers.

Elias, Norbert. 1978. What is sociology? New York: Columbia University Press.

Giddens, Anthony. 1984. The constitution of society : outline of the theory of structuration. Cambridge Cambridgeshire: Polity Press.

Lawson, George and Robbie Shilliam. 2010. "Sociology and international relations: legacies and prospects." Cambridge Review of International Affairs 23(1):69-86.

Tilly, Charles. 1992. Coercion, capital, and European states, AD 990-1992. Rev. pbk. Edition. Cambridge, MA: Blackwell.

Weber, Max. 1978. Economy and society : an outline of interpretive sociology. Berkeley: University of California Press. 